\title{
祝儀袋における水引の印象評価
}

\author{
石橋 賢, 上野 千尋 \\ 熊本県立大学
}

\section{Investigation of Impressions Given by Mizuhiki for Japanese Gift-money Envelopes}

\author{
Ken ISHIBASHI and Chihiro UENO
}

Prefectural University of Kumamoto, 3-1-100 Tsukide, Higashi-ku, Kumamoto-shi, Kumamoto 862-8502, Japan

\begin{abstract}
Mizuhiki is a decorative Japanese cord and used for gift-money envelopes. This study shows our investigation results regarding impressions given by Mizuhiki. The advantages are the clarification for impression structure, the use of an analysis method focusing on two factors, and the development of an interactive visualization tool. First, we got five factors from factor analysis. The factors are gorgeousness, grace, favorability, novelty, and loveliness. We analyzed the relationships between two factors using a robust PCA, thereby we could know some effect factors for increasing or decreasing the impressions belonging to two factors. In addition, we developed a new visualization tool for impressions of Mizuhiki and confirmed the effectiveness via users' experiments.
\end{abstract}

Keywords : Investigation of impressions, Mizuhiki, Japanese gift-money envelopes, Visualization tool

\section{1. は じめに}

近年の日本の伝統的工芸品は, 海外輸出や若年層向けに アレンジされ, 新たな販路開拓を進めている。その背景には, 年々市場が縮小傾向にあり $[1,2]$, 最盛期の生産額の $1 / 4$ 程度 にまで落ち込んでいることが挙げられる [3]. 水引もその 一つであり, 生産額はピーク時の 80 億円以上から 32 億円程度 まで減少している(『日経MJ (流通新聞)』, 2018年3月19日).

水引は, 慶事や串事用途に用いられる贈答用品の包み紙に かける帯紐のことを指し，伝統的工芸品にも指定されている. 水引装飾は, 結び方によって異なる意味を持ち, 伝統的な 結びとして結び切り, 淡路結び, 花結びなどが挙げられる. 例えば, 一度で終わることが良いとされる快気祝いには結び 切りを，何度あっても良いとされる合格祝いには花結びを， 末永く付き合うことが良いとされる結婚祝いには淡路結びを 利用する.ささらに, 伝統的な結びを基本形としたアレンジに より，日常の扮礼から婚礼まで幅広く活用できる。現在では， 海外輸出や若年層の新規開拓を目指し, アクセサリーや箸置き, グラスマーカーといった小物まで用途が拡大している [4-7].

一方で, 伝統工芸に関する先行研究 [1,8-10] では, 感性 (印象) 評価研究により消費者が各対象物に抱く印象を抽出し て商品開発に役立てている. 同様に, 水引に対する印象評価 によって, 商品開発をはじめ, 海外市場の開拓や新たな客層獲 得にも活用できることが見込める．また, 水引の調査報告 [11] では, 水引業者 (製造問屋, 製造業者, 卸・ 小売) の経営状態の 改善策として, 回答業者の過半数が新製品の開発を挙げてお り，印象評価によりそのニーズを満たすことができると考え られる. しかしながら, 水引工芸の専門家以外が水引の印象 について考える機会は少なかったものと考えられ，水引の 結びが与える印象に関する研究はほとんど報告されていない.
そこで本研究では，水引の結びに注目した印象評価を実施 することで，水引装飾の視覚的要素が見た目の印象に与える 影響を明らかにし，印象に基づき水引の装飾を選ぶための 指標を作成する。これにより，商品開発や個人の趣味利用に 至るまで幅広く得られた知見を利活用でき，水引工芸の市場 活性化に繋がる実務的・実践的効果が期待できる。加えて, 本論文の学術的貢献として, 次の 3 点が挙げられる.

貢献1 水引の結びに関する印象構造を明らかにした点.

貢献 2 二因子の印象がともに増減する要因を明らかにした点.

貢献 3 インタラクティブな印象可視化ツールを開発した点.

貢献1では，因子分析により水引の結びの印象構造を明ら かにし，現代アレンジといったリデザインへの新たな知見を

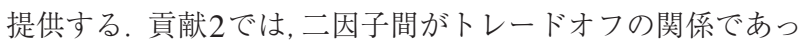
ても，その中で共通して両印象を高めたり，低めたりする要 因を探る分析手法を用いた。貢献3では, 調査結果を一般の 人々にも利用できるような新たな可視化ツールを開発した。 これらは，いずれも印象評価における有意義な取り組みであ り，今後の感性評価研究にも役立つことが見込まれる。詳細 については, 貢献 1 は $3 \cdot 4$ 章, 貢献 2 は 5 章, 貢献 3 は 6 章に て述べる。全体的な結果については，7章にてまとめている。

\section{2. 関 連 研 究}

水引の結びに関連する研究として, 伝統工芸の関連研究, および,リボンの装飾に関する研究について紹介し, 本研究 との関係について述べる。

\section{1 伝統工芸の研究}

上原 [2] は, 伝統的陶磁器において消費者へ付加価値を 理解してもらうことと, 作り手には消費地で求められている 情報が届くようにすることの必要性を述べている，すなわち， 
職人は消費者からの情報を得て, 新しい価值創造を進めて いく必要があることを示唆している。 その例として, 横溝と 村井 [6] は, 海外向け商品のための伊予水引のリデザインに 関する取り組みを報告しており, 文献 [7] では, それらの商品 に対するコンテキスト情報の提示において, 購買意欲がどの ように変化するのか市場調査し, 形の意味や技能に関するコン テキストが購買意欲を高める要因となることを明らかにした。

水引以外の伝統工芸に関する研究では，新たな価值創造を 目的に感性評価のアプローチが用いられている。領家ら [8] は, 石川県の伝統工芸素材に注目して, 九谷焼, 漆, 金筞につ いて各30種のサンプルに対する感性評価データを収集した. 得られたデータでファジィ対応分析を行い, サンプルと感性 ワードの関係を可視化すると同時に, サンプルと感性表現と の類似度を定義した。 さらに, 複数の感性ワードから代替案 を提示する仕組みを構築した。 山下ら [9] は, 九谷焼図柄の 感性評価データと同様の図柄で, 洗面ボールに適用した際の 比較分析を行った。 その結果, 5つのデザインパターンの 分類ごとで, 九谷焼に対する色の濃淡・色調, および, 風格· おもむき因子において, パターン別の変化が現れた，その他 にも, 生け花 [10] や京友禅染 [1] に関する感性評価研究も 報告されている.

伝統工芸は, 情報技術の導入も進められ, 拡張現実感技術 による京友禅染のブランドイメージや生産者情報, SNSや ウェブサイトヘアクセスできる仕組みの構築, および, セカン ドライフ上での京都型友禅や伊勢型紙などの電子アーカイブ 化などの取り組みがある [12]. 宮田ら [3] は, 工芸素材の 質感表現手法をデザイン支援システムに導入することで, 実際の商品開発に効果があることを報告し, 橋田ら [13] は, 感性評価データを洗面ボール形状のデザイン支援システムに 利用した。

\section{2 リボンの装飾に関する研究}

装飾に着目した研究として, リボン装飾の感性評価研究 が挙げられる [14]. 文献 [14]では, 24パターンの異なる リボン装飾の印象を調査し, 因子分析で「絢爛さ, 正統さ, ダイナミックさ」の三因子が抽出された．各因子の傾向を 多重比較により分析した結果, ループ数の増加により絢爛さ やダイナミックさの印象を高めることができ, 横方向への リボンの帯掛けが正統さを高める要因となっていることを 明らかにした。

\section{3 本研究との関係}

従来の水引研究 $[6,7]$ では, 海外輸出向けの新たな知見を 提供しており, 具体的な商品開発, および, 個人利用のための 知見までは含まれていない，そこで本研究では，伝統工芸に おいても実績のある感性評価研究 [1,8-10] のアプローチを 用いることで, 具体的な商品開発や個人利用を可能にする 知見の提供を目指した。 また, リボン装飾の先行研究 [14]で は, 結びのループ数や位置情報, 視覚情報の量的変化が印象 に影響していることが報告されている，水引も類似した形態
であることから, 本研究の分析でも, 水引の本数, ループ数, 装飾の位置についてそれぞれ着目して印象の違いを分析した。 その結果, 水引の結びに関わる5つの因子が抽出され, 各因子 に扔ける結びの特性が統計的分析により明らかになった。 詳細については，4.2節および5章を参照していただきたい.

さらに，情報技術も主流の研究手法となっていることから [3,12,13], 印象評価の結果をシステムに活用することも効果 的なアプローチだといえる。本研究では, 従来の静止画像に よる可視化結果より, 見やすさ, 分かりやすさ, 満足度の向上 を目指した新たな可視化ツールを開発した。評価実験では, 従来に比べて見やすさと満足度の高い可視化ツールであるこ とが認められた。本詳細は，6章を参照していただきたい．

\section{3. 印象評価のための条件設定}

水引の結びに関する印象評価を行うために, 評価対象物, ならびに，評価用語を含む評価方法を決定しなければならな い.ここでは，各条件について述べる，

\section{1 評価対象物の選定}

本調査では，伝統的な結びと現代的にアレンジした結びを 対象とし, 慶事用の一般的な用途を前提に, 水引と金封のみ の最小限の構成で対象物を準備する。 その理由は, 現代的に アレンジした結びがすべて慶事用であり，また，対象物が アクセサリーや箸置きなどの場合，それらに関する興味関心が 印象評価に影響すると考えたからである。そそのため，水引装飾 のある祝儀袋を対象とすることにした，特に金封は，文献 [11] でも新製品の開発競争が激しいと報告されており，本調査に おいて実務的・実践的意義の高い対象物であるといえる.

以上を踏まえて, 水引の色は慶事に用いられる赤色と白色と し, 水引の装飾対象は白無地の金封 $($ 横 $8.8 \mathrm{~cm} \times$ 縦 $17.8 \mathrm{~cm}$ ) とした。調査対象の祝儀袋は, 尉斗や包装紙を使わず直接 水引で装飾することで, 水引以外の印象の影響を考慮した。 結び方の種類は, 水引の書籍 $[4,5]$ から伝統的な結びと現代 的にアレンジした結び，計 15 種を採用した，表1の奇数行に 本稿での結びの略称を, 偶数行に 15 種の水引装飾の名称を それぞれ示す，加えて，水引の本数に注目し，3本と5本の 水引で各結びを作成し, 計 30 個の評価対象物を作成した. 以降, 略称に水引の本数を付けて各調査対象を表記する. 図 1 は, 表 1 に対応した 5 本の水引で作成した装飾例を示す.

\section{表 1 調査対象の水引の装飾名およびその略称}

\begin{tabular}{ccc}
\hline 花結 & 結切 & 片輪 \\
\hline 花結び & 結び切り & 片輪結び \\
\hline 梅結 & 梅帯 & 鎖編 \\
\hline 梅結び & 梅+帯締め & 鎖編み \\
\hline ライン & 抱淡(1) & 抱淡(2) \\
ライン縦 & 抱き淡路結び(1) & 抱き淡路結び(2) \\
\hline 淡(1) & 淡(2) & 淡(3) \\
淡路結び(1) & 淡路結び(2) & 淡路結び(3) \\
\hline 松結 & クロ結 & 王結 \\
\hline 松結び & クローバー結び & 玉結びのリース \\
\hline
\end{tabular}




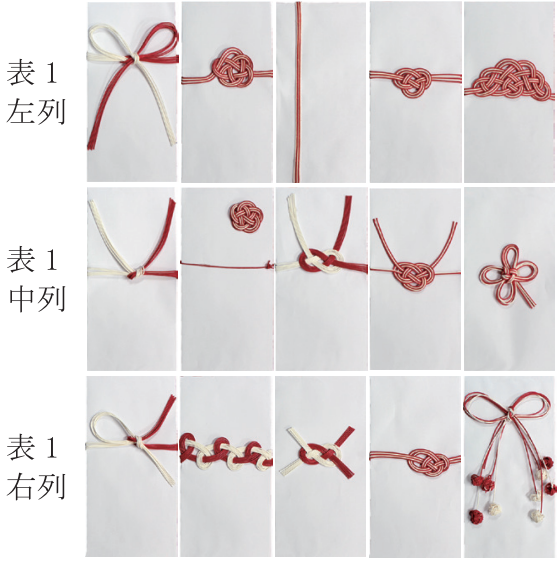

図1 調査対象の水引の例

\section{2 印象評価の方法}

本印象評価では，冒頭で述べた結びの意味が評価結果に影 響すると考えられる。植松と佐藤 [15]の報告では，3つの 慶事利用で適切な水引の種類を選択させたところ, 完答した 大学生は 52 名中 0 名という結果であった。そこで, 結びの 意味の影響が小さく，見た目の印象から評価できる大学生が 適任だと考え，本調査の参加者として募った。評価用語は， 水引に関する書籍 $[4,5]$ から印象を表わす用語をすべて抽出 し，表 2 に示す 20 語を採用した。本印象評価では，水引の 結び方による印象の差異に着目しているため, 各評価用語に ついて，5段階の評定尺度法を採用し，「感じない」，「あまり 感じない」,「やや感じる」,「感じる」,「とても感じる」の評価 基準で評価してもらった，分析においては，得られた結果を 印象評価值として $1 〜 5 に$ 変換している。また，恒常誤差によ る順序効果やアンカー効果を軽減するために, 評価対象物の 提示順，および，評価用語の評価順はランダムとした．

\section{4. 印象評価の詳細および因子分析の結果}

3 章で述べた条件および手順で印象評価を行った。ここで は, 印象評価の詳細, ならびに, その結果について述べる。

\section{1 印象評価の詳細}

本印象評価には, 18 歳〜22歳の大学生 40 名（女性 20 名, 男性20名）が参加した。実施環境は，昼白色の蛍光灯のあ る部屋であり，すべての参加者が同一の部屋で行った。また， 評価対象物は，上下を確認して形が崩れないように提示し た，回答の制限時間は設けていないが，すべての評価が終わ るまでに 30〜40分程度であったため，一つの評価対象物に 対して平均 $1 \sim 2$ 分程度で評価している.

\section{2 因子分析の結果}

印象評価により得られたデータを 1 〜の印象評価值として 扱い，本データ群 $(30$ 種 $\times 20$ 語 $\times 40$ 人) を用いて因子分析 （最尤法, 独立クラス夕回転）を行った. 因子数は, 対角 SMC 平行分析の提案に従い 5 因子に設定し, $\mathrm{KMO}$ の標本妥当性は
表2 因子分析 (独立クラスタ回転, 最尤法) の結果

\begin{tabular}{|c|c|c|c|c|c|c|}
\hline 評価用語 & $\mathrm{I}$ & II & III & IV & $\mathrm{V}$ & 共通性 \\
\hline 重厚感 & 0.85 & -0.08 & -0.20 & -0.07 & -0.06 & 0.55 \\
\hline 優雅な & 0.62 & 0.11 & 0.08 & -0.02 & 0.11 & 0.49 \\
\hline 高級感 & 0.60 & 0.09 & 0.23 & -0.05 & -0.18 & 0.52 \\
\hline 華やかな & 0.56 & -0.15 & 0.13 & 0.07 & 0.16 & 0.62 \\
\hline 縁起の良い & 0.43 & 0.11 & 0.21 & -0.27 & 0.09 & 0.41 \\
\hline 動きのある & 0.41 & -0.13 & -0.09 & 0.29 & -0.07 & 0.28 \\
\hline クールな & 0.04 & 0.70 & -0.06 & 0.13 & -0.12 & 0.51 \\
\hline シンプルな & -0.38 & 0.57 & -0.03 & -0.16 & 0.18 & 0.53 \\
\hline スタイリッシュな & -0.01 & 0.57 & 0.00 & 0.08 & 0.05 & 0.27 \\
\hline シックな & 0.02 & 0.51 & 0.04 & -0.16 & 0.04 & 0.33 \\
\hline 大人っぽい & 0.27 & 0.50 & 0.09 & -0.07 & -0.08 & 0.39 \\
\hline センスのある & -0.01 & -0.06 & 0.87 & 0.07 & -0.12 & 0.66 \\
\hline おしゃれな & 0.10 & -0.04 & 0.53 & 0.18 & 0.12 & 0.56 \\
\hline 美しい & 0.23 & 0.13 & 0.53 & -0.02 & 0.06 & 0.52 \\
\hline 個性的な & 0.17 & 0.05 & -0.05 & 0.70 & 0.02 & 0.51 \\
\hline モダンな & 0.04 & 0.08 & 0.17 & 0.65 & 0.16 & 0.62 \\
\hline アンティークな & 0.26 & 0.27 & -0.12 & -0.46 & 0.01 & 0.40 \\
\hline ふんわりとした & 0.23 & -0.10 & -0.15 & -0.09 & 0.72 & 0.56 \\
\hline 可愛らしい & -0.02 & -0.12 & 0.24 & 0.02 & 0.56 & 0.59 \\
\hline カジュアルな & -0.15 & 0.29 & -0.02 & 0.26 & 0.48 & 0.27 \\
\hline 寄与率 $[\%]$ & 29 & 21 & 19 & 17 & 14 & \\
\hline 累積寄与率 [\%] & 29 & 50 & 69 & 86 & 100 & \\
\hline 因子相関 & $\mathrm{I}$ & III & III & IV & V & \\
\hline II & -0.12 & - & -0.01 & -0.45 & -0.49 & \\
\hline III & 0.61 & -0.01 & - & 0.17 & 0.57 & \\
\hline IV & 0.15 & -0.45 & 0.17 & - & 0.48 & \\
\hline $\mathrm{V}$ & 0.29 & -0.49 & 0.57 & 0.48 & - & \\
\hline
\end{tabular}

0.89, Bartlettの球面性検定での有意確率は 0.00 となり，本因 子分析の妥当性が示された。表 2 は，因子分析の結果である.

表中の太字で示す数值は, 0.40 以上の絶対值で 5 因子中 最も高い因子負荷量を示す。各因子の下位尺度の内部一貫性 を $\omega$ 係数により検討したところ, 因子 I から順に $0.78 ， 0.71$, 0.78，0.70，0.66となり，一定の信頼性が確認できた．

表2より, 因子 I は「重厚感, 優雅な, 高級感, 華やかな, 縁起の良い，動きのある」といった格式高さや豪華さに関す る項目が高い值を示したため,「絢爛さ」因子と名付けた。 リボンの先行研究 [14]においても，類似した因子が抽出さ れており，紐の結びに共通した因子だといえる。因子II は, 「クールな, シンプルな, スタイリッシュな, シックな, 大人っ ぽい」といった洗練され品のある様子の項目が高い值を示し たため,「上品さ」因子と名付けた. 因子吕は,「センスのある, おしゃれな，美しい」という見た目の好ましさに関する項目 があり，「好ましさ」因子と名付けた。因子IVは，「個性的な， モダンな,アンティークな」といった斬新で新しい項目が 高い值を示したため,「目新しさ」因子と名付けた。因子Vは, 「ふんわりとした，可愛らしい，カジュアルな」といった フェミニンで飾り気のない項目があり，「愛らしさ」因子と 名付けた

\section{5. 印象評価の分析および考察}

水引の結びの印象構造について，分析および考察により 明らかにする。各因子の結果は，最初に箇条書きにて得られ た知見を提示し,続けて統計的分析の詳細について説明する。 


\section{1 各因子の分析結果}

因子分析の結果から算出した下位尺度得点を用いて, 各因子 の特徵について分析する. 本分析では, 水引の本数, ループ数, そして位置の要素に注目する，水引の本数は，各結びで異な る本数を利用しているため, これらを比較する。ループ数に ついては,「結切, 片輪, 花結, 玉結」がそれぞれ「ループなし, 1 ループ, 2 ループ, 2ループ+玉の装飾」であるため, これら を比較する，位置の変化については，梅結と梅帯が同種であ りつつ位置が異なるため, 比較して因子ごとの特徴を明らか にする，なお，淡(1)と淡(3)も位置の比較が可能ではあるが, 多重比較にて差異が確認できなかったため, 本分析の議論に は含まないものとする。

本分析では, 各因子の下位尺度得点に対して, Bartlett検定 で等分散性を検証し，等分散であった因子 I， II， III，V (絢爛さ, 上品さ, 好ましさ, 愛らしさ) について, 各結びでの 一元配置分散分析を実施し, すべての因子にて統計的有意差 が確認できた。 そこで, Holm法による多重比較検定を行い, 各結び間での印象の違いを分析する。一方，不等分散であっ た因子IV (目新しさ) はFriedman検定を行い, 統計的有意差 が確認できたため, 同様にHolm法による多重比較検定を 行い, 各結び間での印象の違いをみる，ただし，不等分散で あるため, 多重比較はWilcoxonの符号付順位検定により 実施した。なお，本分析はすべて有意水準 5\%で議論するも のとし, 以下の各因子の結果は, 統計的有意差がみられた部 分のみ述べる。

\section{因子 I I 絢爛さ因子}

・水引の本数が増えると絢闌さが高まる。ただし,「松結, クロ結, ライン」は除く.

・ループ数の増加と玉の装飾は, 絢爛さを高める要因である. ・ループ数による絢闌さへの影響は, 水引の本数より大きい.

本数の要素 : 同じ名称の 3 本と 5 本の結び同士で,「松結, クロ結, ライン」以外の 12 種の結びで統計的有意差がみら れた. 水引の本数が増えることで, 結びの見た目の大きさが 変化し, 絢闌さを向上させたものと考えられる. ラインは, 結び目がなく本数の増減による見た目の変化もそしい，また， 松結とクロ結は, 3 本の場合でも一定以上の絢爛な印象を 与える. そのため, 本数の比較で違いがみられなかったと考 えられる。

ループ数の要素: 表 3 は, 異なるループ数における多重比較 検定の有意確率であり, 赤字は有意水準以下の数值, 網掛け は3本と 5 本同士での比較結果を表わす.

表3 絢爛さ因子の多重比較 | ループ数の比較

\begin{tabular}{c|ccccccc}
\hline 因子 I & 結切 3 & 片輪 3 & 花結 3 & 玉結 3 & 結切 5 & 片輪 5 & 花結 5 \\
\hline 片輪 3 & 0.00 & - & - & - & - & - & - \\
花結 3 & 0.00 & 1.00 & - & - & - & - & - \\
玉結 3 & 0.00 & 0.07 & 0.52 & - & - & - & - \\
結切 5 & $\mathbf{0 . 0 1}$ & $\mathbf{1 . 0 0}$ & $\mathbf{1 . 0 0}$ & $\mathbf{0 . 0 0}$ & - & - & - \\
片輪 5 & $\mathbf{0 . 0 0}$ & $\mathbf{0 . 0 4}$ & $\mathbf{1 . 0 0}$ & $\mathbf{1 . 0 0}$ & 0.00 & - & - \\
花結 5 & $\mathbf{0 . 0 0}$ & $\mathbf{0 . 0 0}$ & $\mathbf{0 . 0 0}$ & $\mathbf{1 . 0 0}$ & 0.00 & 0.19 & - \\
玉結 5 & $\mathbf{0 . 0 0}$ & $\mathbf{0 . 0 0}$ & $\mathbf{0 . 0 1}$ & $\mathbf{0 . 0 1}$ & 0.00 & 0.38 & 1.00 \\
\hline
\end{tabular}

結切 3 と結切 5 の各列における網掛け領域をみると, すべて 統計的有意差がある。 また, 結切より他の結びの值が高かっ たことから、ループなしょりループあり（＋玉の装飾）が絢爛さ を高めることがわかる. 前述の本数の要素では, 3 本より 5 本 の水引が絢爛さを高めていた，ここで, 結び方の影響度合いを 確認するため, 3 本と 5 本の組み合わせに注目する，5本の場合 の下位尺度得点の平均值は,「玉結 $5>$ 花結 $5>$ 片輪 $5>$ 結切 5 」 の関係となっている。表 3 太字の結果 (3本との比較結果) で も,「玉結 $>$ 花結 $\geq$ 片輪 $\geq$ 結切」の関係が確認でき, 絢爛さへ の影響は, 水引の本数よりもループ数が大きいといえる.

\section{因子 II I上品さ因子}

・ループ数は上品さの印象にあまり影響しないが，玉の装飾 は上品さの印象を低下させる，ただし例外として，水引が 5 本の場合は, 2 ループよりループなしが上品さを高める。 ・ 水引の本数が少なく右上配置の梅の装飾が上品さを高める. ループ数の要素 : 結切 5 と花結 5 との間で統計的有意差が認 められ, 結切 5 の平均值が高いことから, ループなしが上品 さを高めるといえる。また，玉結 3 と玉結 5 はともに，その 他の結びとの間で統計的有意差が確認できた。 玉結の平均值 は低いため，玉の装飾が上品さを低下させることがわかる．

位置の要素 : 中央配置（梅結 5) と右上配置（梅带3）のみ 統計的有意差が確認でき, 上品さを高める条件は, 水引の 本数が少ない右上配置であるといえる.

\section{因子III | 好ましさ因子}

・抱淡(2)のみ, 水引の本数を増やすと好ましさが高まる.

・ループなしよりも，2ループが好ましさを高める。

本数の要素：帯を持たない抱淡(2)では， 3 本と 5 本間で統計 的有意差がみられ，この結びのみ水引の本数の増加により印 象を高める傾向が認められた。

ループ数の要素 : ループ数の異なる結びでは, 3 本と 5 本いず れも「花結一結切」「玉結一結切」間で統計的有意差が確認で

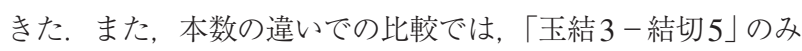

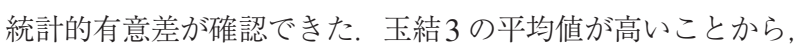
2ループかつ玉の装飾がある場合，ループなしよりも好ましさ を高める傾向にあり，本数の要素よりも強い影響を与えるこ とが明らかになった。

\section{因子IVI目新しさの因子}

-玉の装飾が目新しさを高め, 1 ループも同等の印象を持つ. ループ数の要素 :「玉結 5-結切 $3(5) 」$,「玉結 5-花結 3 (5)」 間で統計的有意差が確認でき,「玉結 5 -玉結 3」,「玉結 3 (5) 一片輪 3（5）」間では有意差がみられなかった。下位尺度得点 の平均值は, 「玉結 $5>$ 玉結 $3>$ 片輪 $3>$ 片輪 $5>$ それ以外」であ ることから, 有意差がみられた玉の装飾は目新しさを高め, 1ループも同程度の目新しさの印象を持つことが確認できた。

\section{因子VI爱らしさの因子}

・ループ数の増加により愛らしさを高め, 玉の装飾もその効 果を高める.

ループ数の要素 : 表 4 は, 異なるループ数の多重比較検定の 有意確率であり, 赤字は有意水準以下の数值, 網掛けは 3 本 と 5 本同士での比較結果を表わす。 
表4 愛らしさ因子の多重比較 | ループ数の比較

\begin{tabular}{c|ccccccc}
\hline 因子 II & 結切 3 & 片輪 3 & 花結 3 & 玉結 3 & 結切 5 & 片輪 5 & 花結 5 \\
\hline 片輪 3 & 1.00 & - & - & - & - & - & - \\
花結 3 & 0.04 & 1.00 & - & - & - & - & - \\
玉結 3 & 0.00 & 0.00 & 0.01 & - & - & - & - \\
結切 5 & $\mathbf{1 . 0 0}$ & $\mathbf{1 . 0 0}$ & $\mathbf{0 . 0 1}$ & $\mathbf{0 . 0 0}$ & - & - & - \\
片輪 5 & $\mathbf{1 . 0 0}$ & $\mathbf{1 . 0 0}$ & $\mathbf{0 . 2 4}$ & $\mathbf{0 . 0 0}$ & 1.00 & - & - \\
花結 5 & $\mathbf{0 . 0 1}$ & $\mathbf{0 . 2 9}$ & $\mathbf{1 . 0 0}$ & $\mathbf{0 . 0 3}$ & 0.03 & 0.10 & - \\
玉玉結 5 & $\mathbf{0 . 0 0}$ & $\mathbf{0 . 0 0}$ & $\mathbf{0 . 0 5}$ & $\mathbf{1 . 0 0}$ & 0.00 & 0.00 & 0.11 \\
\hline
\end{tabular}

同一本数での比較では, 3 本と 5 本で共通して,「花結 - 結切」, 「玉結－結切」，「玉結－片輪」間で，3本のみ「玉結－花結」間 で統計的有意差が確認できた。また, 本数の違いによる比較 では，表4の太字に注目すると，統計的有意差の有無から 「玉結 $>$ 花結 $\geq$ 片輪 $\geq$ 結切」の関係性がわかり, 下位尺度得点 の平均值からも確認できた。すなわち、ループ数が増加する ことで, 愛らしさの印象は高まる傾向にあり, 玉の装飾はそ の効果をより高める要素だとわかる.

\section{2 二因子間の分析結果}

二因子の関係性をみるために，下位尺度得点を用いた相関 分析, ならびに，主成分分析を用いた二因子の印象がともに 増減する要因を明らかにするための分析を行う。表5は, MCD（Minimum Covariance Determinant）を用いたロバスト 相関表であり，下位尺度得点から二因子間の相関係数を算出 した。

表 5 より, 上品さは他の因子と負の相関がみられ, 他の 因子間では正の相関がみられる。特に，絢爛さと好ましさは 強い相関関係にあり，絢爛さが高まると好ましさも高まる ことがわかる。そその他も中程度の相関がみられる。また， 上品さと愛らしさは中程度の負の相関がみられ, トレード オフの関係にあることがわかる。ささらに，主成分分析と クラスタリングにより，二つの因子間の関係性をより詳細 に分析する

図 2 は, 二因子軸での下位尺度得点平均の分布，および, 射影追跡法と MCD によるロバスト主成分分析の第一・第二 主成分軸を示す。ここでは, 二因子の下位尺度得点が同程度 の結びに注目することで, 両者の印象を増減させる要因につ いて考察する，そのため，すべて傾きが正の主成分軸（赤線） に注目する。図2の有彩色の点群は考察対象の結び群であ り，傾きが負の主成分軸（グレー線）の95\%信頼区間を基準 に決定した。これは，いずれかの因子が高い，あるいは， 低い結びを除外することで, 両者の印象を増減する要因を厳

\section{表5＼cjkstart因子間のロバスト相関表}

\begin{tabular}{c|rcccc}
\hline 因子名 & 絢爛さ & 上品さ & 好ましさ & 目新しさ & 愛らしさ \\
\hline 絢 爛 さ & 1.00 & - & - & - & - \\
上 品 さ & -0.33 & 1.00 & - & - & - \\
好ましさ & 0.72 & -0.30 & 1.00 & - & - \\
目新しさ & 0.54 & -0.22 & 0.54 & 1.00 & - \\
愛らしさ & 0.55 & -0.51 & 0.64 & 0.58 & 1.00 \\
\hline
\end{tabular}

密に分析するためである。本考察では, 考察対象の結び群を Fuzzy cmeans 法を用いたクラスタリングにより上位 (赤), 中位 (橙, 黄), 下位 (緑)のクラスタに分けて議論する. クラスタ数の決定には, Xie-Beni型妥当性尺度を用いた。 本尺度は，值が小さいほどクラスタ分割の妥当性が高いこと が示され, クラス夕数を 3 と 4 で比較して低い值を示した クラスタ数を採用した。 また，各グループ間において， 5.1 節で述べた手順と同様に Holm法による多重比較検定 （有意水準 5\%）を実施した。以下に，その分析結果から 得られた二因子の印象を高める, あるいは, 低める要因につ いて述べる.

\section{$「 \mathrm{I}$ 絇爛さー II 上品さ」Iクラスタ数 4}

- 水引の本数と装飾の具象性を減らすと, 両印象を高める. 図 2 (a) より「上位 (赤) -下位 (緑)」,「中位 1 (橙) 一下位 (緑)」 間で統計的有意差がみられた。 上位と中位 1 は, 抱淡(1) 5 , 抱淡(2)5, 淡(3) 5 が属し，下位はクロ結 3 が属する。クロ結は 縁起物を模した結びであり，装飾の具象性が高い。同様に, 下位との間では統計的有意差がみられなかった中位 2 (黄) は，梅帯3が属しており，水引3本かつ装飾の具象性が高い 点が共通している. よって, 水引の本数と具象性の減少が, 両印象の低める要因である傾向が確認できる.

\section{「I 絢爛さーIII好ましさ」|クラスタ数 3}

- 水引の本数とループ数を増やすと, 両印象を高める.

図2 (b) より,「上位 (赤) -下位 (緑)」,「中位 (橙) 一下位 (緑)」 間，㧍よび，「梅結 5 (赤) - 中位 (橙)」間でも，統計的有意 差が認められた，上位は，水引5本かつループ数が多い結び が多く属し，中位と下位は，水引3本かつループ数も少ない 傾向にある. よって, 水引の本数とループ数の増減が, 両印 象を増減する要因であると考えられる。

\section{「I 絢爛さ-IV目新しさ」|クラスタ数 4}

- 水引の本数と装飾の複雑性を増やすと, 両印象を高める. 図 2 (c) より,「上位 (赤) - 中位 2 (黄)」,「上位 (赤) -下位 (緑) 」 間で統計的有意差が確認できた。 上位は水引 5 本かつ装飾 が複雑な傾向があり, 中位 2 と下位は水引 3 本かつ装飾が シンプルな特徵がある。上位との間で統計的有意差がみら れなかった中位 1 (橙) も, 水引 5 本や複雑な装飾の両方, または, いずれかの特徵を持つ結びが属する。 よって, 水引 の本数と装飾の複雑性の増加が, 両印象を高める要因だと いえる，特に，「淡(3)5-淡(3)3」間で有意差があったこと から, 右配置の淡路結びは, 水引の本数を増やすと, 両印 象を高める。

\section{「I 絇爛さーV 愛らしさ」Iクラスタ数 3}

- 玉の装飾は両印象を高め, 縦方向の装飾は両印象を低める. 図 2 (d) より,「上位 (赤) -下位 (緑)」間, および,「玉結 5, 玉結 3 (上位) - 淡(2)3, 花結 3 (中位)」の各組み合わせ間で, 統計的有意差が認められた。下位の結びは，すべて縦方向の 装飾があり，それらが両印象を低めたものと考えられる。 一方，玉結は両印象が高く，類似した結びである花結とも 有意差がみられることから，玉の装飾を付けることが両印象 を高める要因となっていることがわかる. 


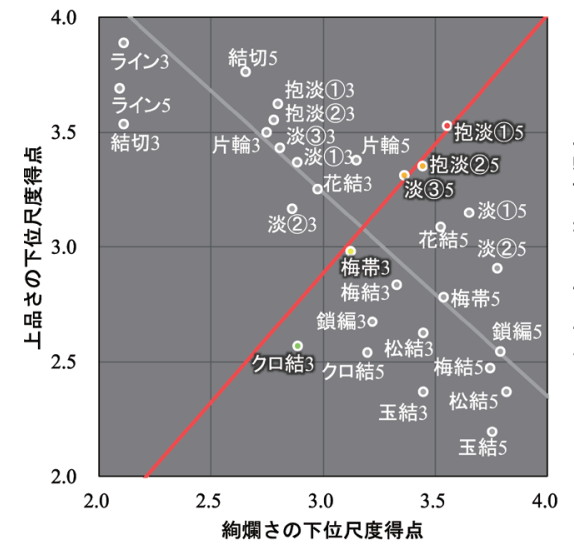

(a ) 絢爛さ一上品さ

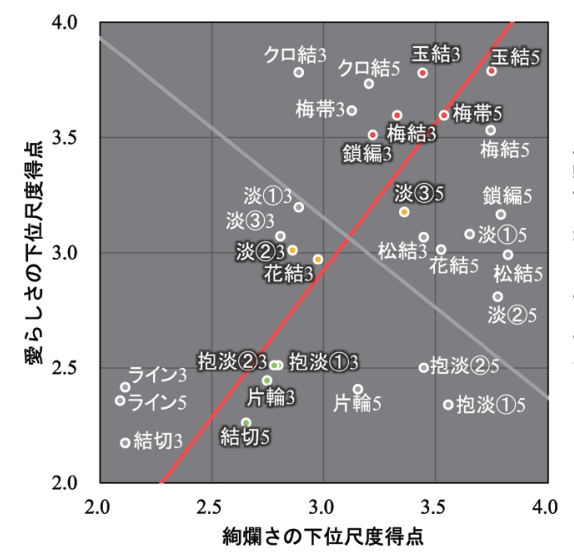

(d) 絈爛さ一愛らしさ

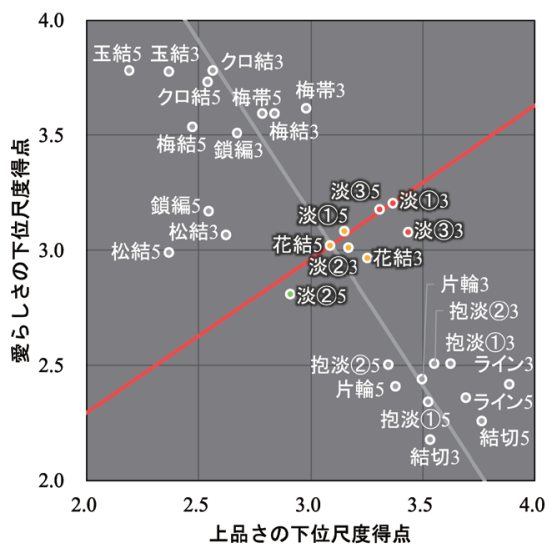

（g）上品さ一愛らしさ

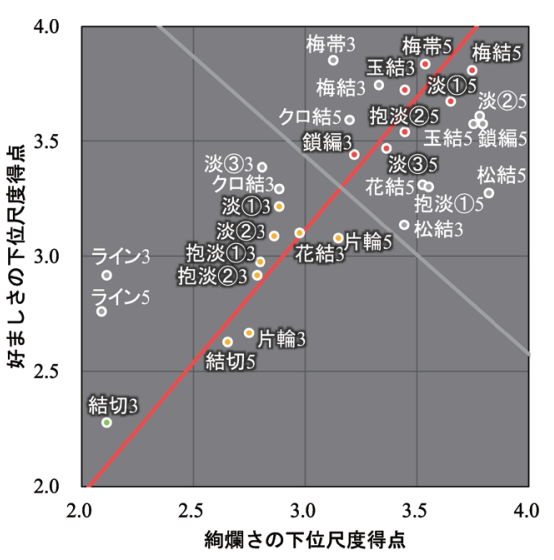

(b) 絢爛さ一好ましさ

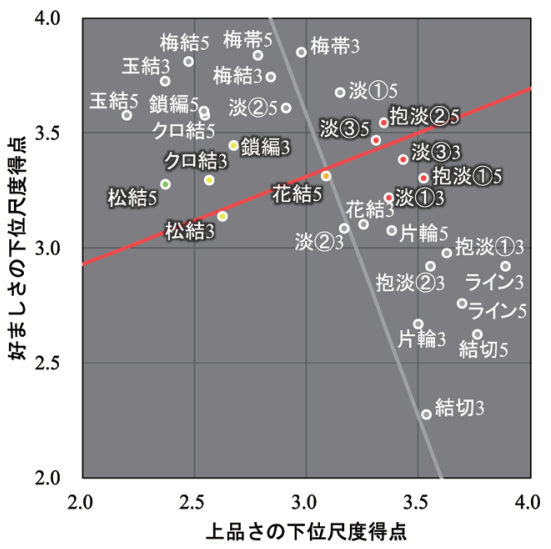

(e) 上品さー好ましさ

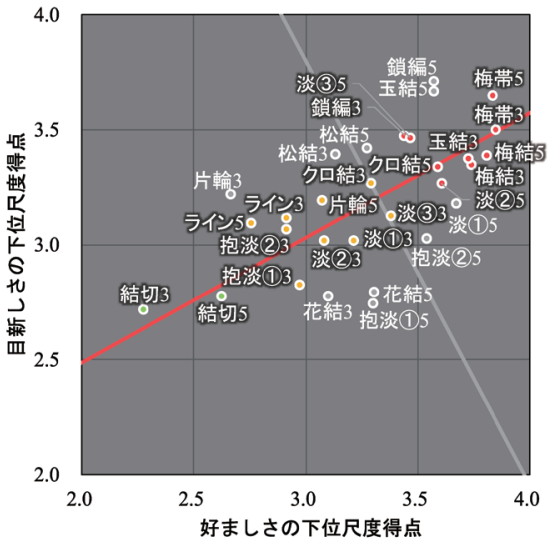

(h) 好ましさー目新しさ

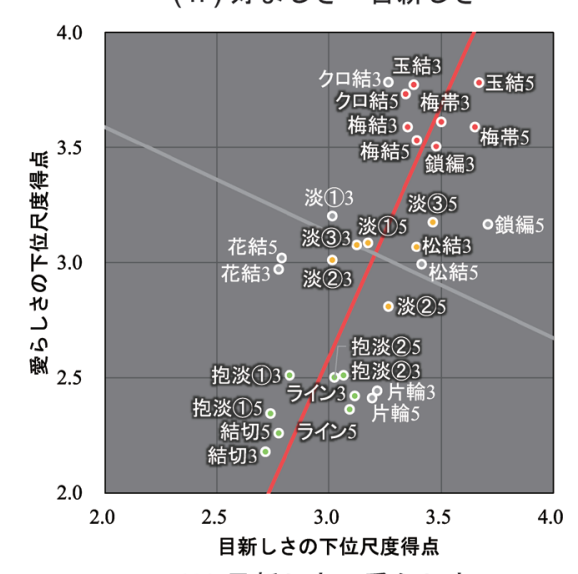

(j) 目新しさー愛らしさ

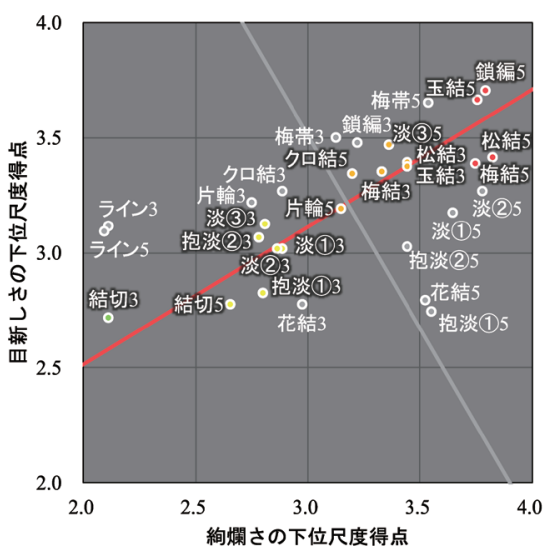

(c) 絈爛さ一目新しさ

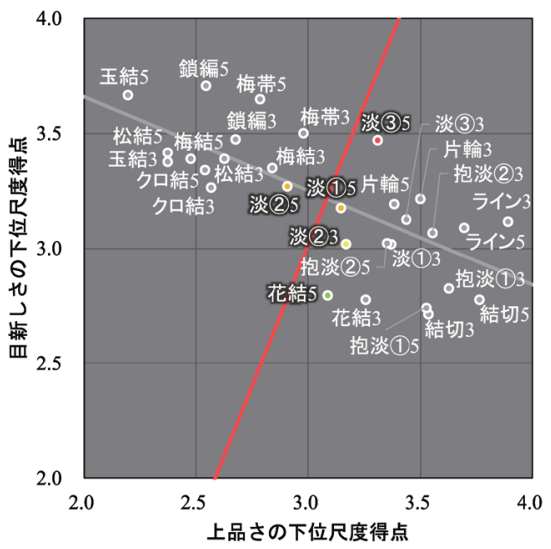

(f) 上品さ一目新しさ

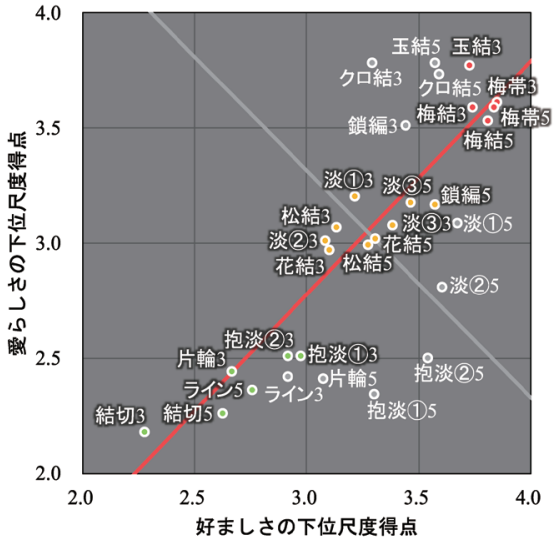

(i) 好ましさ一愛らしさ

図2 二因子軸における下位尺度得点の平均値および主成分分析の結果 


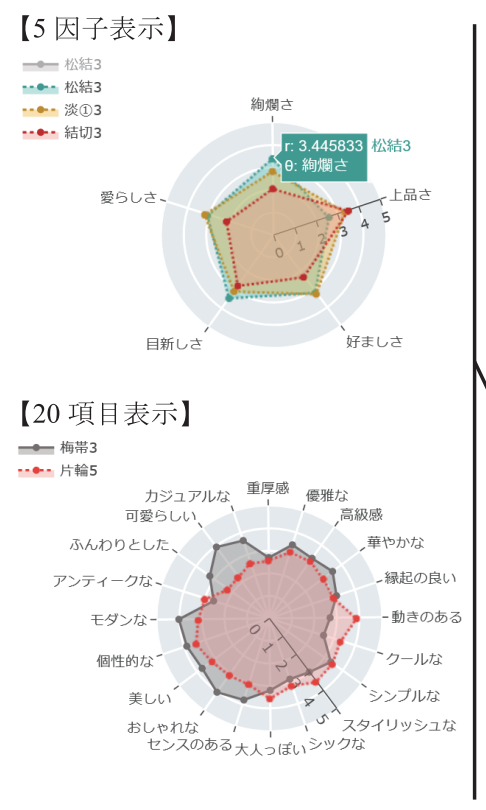

(B)

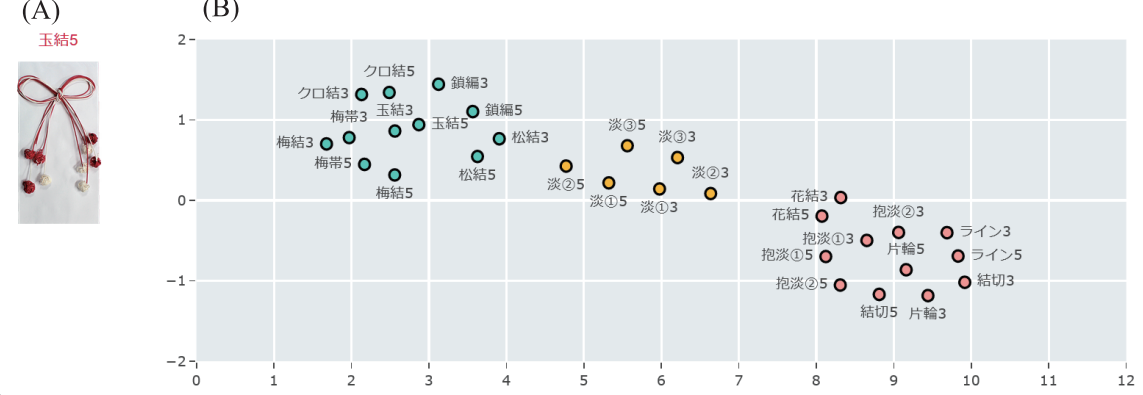

(C)【詳細表示】

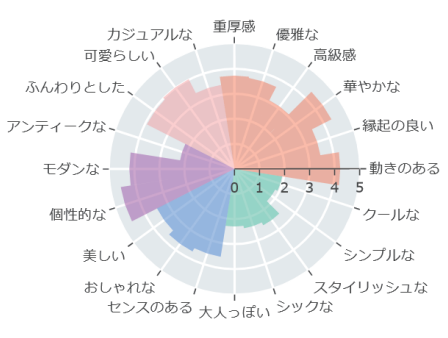

(D)

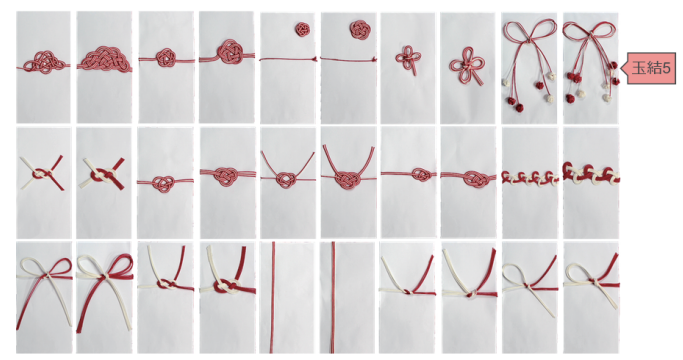

図3＼cjkstart水引の結びに関する印象可視化ツール

\section{「II 上品さーIII好ましさ」Iクラスタ数 4}

・淡路結び（淡(1)(3), 抱淡(1)(2)）が両印象を高める.

・現代的なアレンジ (松結, クロ結, 鎖編) は両印象を低める. 図2 (e) より,「上位 (赤) - 中位 2 (黄)」(「淡(1) 3 - 鎖編 $3 」$ 間 を除く),「上位 (赤) -下位 (緑)」間で統計的有意差が認めら れた，上位は，(抱き) 淡路結びが属しており，中位 2 や位 は現代的なアレンジが属している. よって, 現代的なアレンジ が両印象を低め, 縦方向への装飾のない(抱き) 淡路結びが 両印象を高める傾向にある。

\section{「II 上品さーIV目新しさ」|クラスタ数 4}

・淡路結び, 特に水引 5 本右配置の淡(3) 5 が両印象を高める. 図 2 (f) より,「淡(3) 5 (上位) - 花結 5 (下位)」間のみ統計 的有意差が確認できた，考察対象のほとんどが淡路結びで あり，5本水引が上位 (赤) や中位 1 (橙)に属する.よって, 淡路結びは, 上品さと目新しさのバランスが取れた結びで あるといえ, 特に水引 5 本で右配置の淡(3) 5 は両印象が高い.

\section{$「$ II 上品さーV愛らしさ」Iクラスタ数 3}

・淡(2) 5 は, 他の淡路結びに比べて, 両印象を低める.

図2 (g)より,「淡(1)3, 淡(3) 5 (上位) - 淡(2)5 (下位)」間で 統計的有意差が確認できた。淡(2)3は中位 (橙)にあること からも, 水引5本で上方向の装飾がある淡(2) 5 のみ, 両印象 が低い傾向にあることがわかる.

\section{「III好ましさーIV目新しさ」Iクラスタ数 3}

- 梅や玉の装飾は両印象を高め, 結切は両印象を低める. 図 2(h)より，「上位 (赤) -下位 (緑)」間で統計的有意差 がみられた。上位は梅や玉の装飾があり，下位はシンプルか つ伝統的な結びである結切である。よって, 梅や玉の装飾が 両印象を高め, 結切は両印象を低める結びだといえる.

\section{「III好ましさ $-\mathrm{V}$ 愛らしさ」Iクラスタ数 3}

- 梅や玉の装飾は両印象を高め, 縦方向の装飾は低める. 図 2(i)より,「上位 (赤) -下位 (緑)」間で統計的有意差が
みられた。上位は梅や玉の装飾があり，下位は縦方向の装飾 を持つ結び (抱淡(1)(2), 片輪, ライン, 結切) は, その両方の 印象を減少させる傾向にある。

$\lceil I V$ 目新しさ $-V$ 愛らしさ」因子間 (クラスタ数 3)

- 梅や玉の装飾は両印象を高め, 縦方向の装飾は低める.

図 $2(\mathrm{j})$ より,「上位 (赤) 一下位 (緑)」間で有意差が認めら れた。「好ましさー愛らしさ」因子間と類似した傾向があり， 梅や玉の装飾，および，縦方向の装飾が両印象を左右する.

\section{6. 印象可視化ツール}

情報可視化は，一般の人々にとってもその内容を利活用す るために有用な技術である。近年の感性評価研究 $[16,17]$ で は，評価デー夕を2次元に布置する手法が用いられている。 印象構造をみるには有用な方法ではあるが，個別の印象の差 異を確認することはできない，そこで，全体と個別の印象を 確認できる印象可視化ツールの開発に取り組んだ。本ッール は，因子得点による2次元の散布図（全体への対応），下位 尺度得点によるレーダーチャート (個別への対応)，そして 水引一覧をそれぞれ連携させた対話型の可視化ツールであ る。図 3 は，開発したツールの例である。次に，本ッールの 機能および評価について述べ，その有用性を議論する。

\section{1 可視化ツールの各種機能}

本ツールは, 図3に示す（A）～(D) の領域で構成される. 以下に，各領域の機能について述べる。

\section{(A) 選択中の水引}

（B）あるいは（D）で選択中の水引画像と名称を表示する.

\section{(B) 印象マッフ}

印象マップは，40名分の因子得点を用いてUMAP [18] により二次元に次元縮小した後, HDBSCAN [19］による 
クラスタリングにて色分けした。 なお, 各パラメータは, 先行研究 $[18,19]$ に基づき推奨設定の範囲でUMAPでは (n_neighbors=10, n_components $=2$, min_dist $=0.1$, metric='correlation'), HDBSCANでは（metric='euclidean', min_cluster_size $=3, \min \_s a m p l e s=1 ）$ とした. 点同士のユーク リッド距離は，印象の非類似度を表わしている。ユーザは， 各点にマウスオーバーすることで, 選択中の水引を変更で き，(A）と（C）の結果も自動更新される，さらに，各点を マウスクリックすることで, 図3左に示すように複数の結果 を比較でき, クリックされた点は白色に変わる。

(C) レーダーチャート

個別の印象デー夕の可視化には, 先行研究 [14]でも利用 されているレーダーチャートを採用した，本ツールでは， 任意に表示形式を切り換えられ，各水引の比較も可能である. レーダーチャートの表示形式は, 下位尺度得点平均で表記 する 5 因子表示, 評価項目別の印象評価值平均で表記する 20 項目表示, その両方を表記する詳細表示を実装した. 共通の機能と各機能は以下のとおりである.

共通の機能 : 各項目名と評価值の軸は, 任意に回転可能で あり，比較データは凡例のクリックにより，表示/非表示を 選択できる，さらに，レーダーチャートをマウスオーバーす ると，図3左上のようにツールチップで詳細を確認できる。

5因子表示 : 下位尺度得点の平均值を確認できる。（B）また は (D) で各点や画像をクリックすると, 選択中の水引の結果 が固定され, 図3左のように複数の結果を比較できる。なお, 色分けは, (B) 印象マップのクラスタ色に対応している.

20 項目表示 : 評価項目別の平均值を確認できる. それ以 外は, 5 因子表示と同じ機能を持つ.

詳紼表示：5因子と 20 項目の結果を確認できる。マウス オーバーにて, 外側領域で 20 項目の值が, 内側領域で 5 因子 の值がッールチップで表示される。ただし, 比較機能はない.

\section{（D）結びの一覧}

30 種の水引画像が表示され，（B）と同じようにマウス オーバーとクリックで, (A) と (C) の結果が変更される. また，（B）とも連動しており，（B）で一つの点をクリックす ると，（D）では対応する結びに枠線が表示される。

\section{2 評価実験および考察}

本ッールの効果を検証するために，12名の大学生（うち, 女性 8 名）を募り評価実験を行った。本評価実験では, SUS (System Usability Scale) [20］によるユーザビリテイ評価, ならびに, 本ツールと静止画像（詳細表示のみ）の比較評価を 実施した。 なお，本ッールの体験時間は，一人あたり5分とした。

SUSは，ユーザビリティに関する10の質問項目に対して， 5段階のリッカート尺度で評価した後，文献 [20］の手順で [0,100]の範囲でスコア化し，70以上のスコアであれば, 許容 可能なインターフェースであることを示す指標となる [20]. また，比較評価は，従来手法である静止画像（詳細表示のみ） による可視化結果を別途提示し，見やすさ，分かりやすさ， 満足度の三項目に対して5段階のリッカート尺度で評価して
もらい, 同様の質問項目と評価尺度で本ツールも評価しても らった，さらに，表示形式の有用性の比較調査として，各表示 形式を有用な順に並び替えてもらうアンケート調査も行った。

評価実験の結果, SUSスコアの平均は 70.83 となり, 本ッー ルが許容可能なインターフェースであることが実証された. また, 比較評価の結果をみると, 本ッールの平均值は「見や すさ 4.08 , 分かりやすさ 4.00 , 満足度 3.80 」, 従来手法である 静止画像の平均值は「見やすさ 2.58 , 分かりやすさ 3.50 , 満足度3.33」となり, 見やすさと満足度の項目において, $t$ 検定 にて統計的有意差 $(t(11)=3.76,3.32, p<.05)$ が確認できた. これは，従来手法と比べてインタラクティブにユーザが所望 する情報を取捨選択できることが見やすさを向上させ，結果 として満足度が向上したものと考えられる。一方で, 分かり やすさの項目で有意差がみられなかった理由として，6.1節で 述べた共通の機能が，ユーザにとってやや複雑に感じられた ことが挙げられる，通常の場合，マウスオーバーとマウス クリックによるレーダーチャートの比較機能のみ利用するこ とになるが, ユーザによっては軸の回転やレーダーチャート の表示/非表示機能も利用することで操作が煩雑に感じられ, 分かりやすさの評価が低下したことが想定される。 なお, 表示形式の有用性の比較調査結果に対して, Friedman検定を 行ったところ, 統計的有意差が認められなかったため，3つの 表示形式はすべて同程度の有用性を持つといえる.

印象マップでは, 現代的アレンジ群 (緑色), 淡路結び群 (黄 色), 伝統的結び群 (赤色) に分類された。この結果から, 淡路結びは, 伝統的結びでありながら, 現代的にアレンジし た印象も兼ね備えた結びであることがわかる.

\section{7. おわりに}

本研究では, 祝儀袋における水引の結びを対象に印象評価 を行い, 因子分析によりその印象構造を調査した。 また，その 印象評価結果を活用した可視化ツールを開発し，SUSスコア によるユーザビリテイ評価，ならびに，従来手法である静止 画像との比較評価によりツールの有効性を検証した。各まと めと全体の考察, および, 将来の展望は, 次のとおりである.

\section{因子分析の結果（因子別）}

- 因子分析により，I 絢爛さ，II上品さ，III好ましさ，IV 目新 しさ，V愛らしさの5因子が抽出された。

・I 絢爛さ : 水引の本数とループの増加, および, 玉の装 飾が付けることで絢爛さを高める。 ただし, 水引の本数 よりループ数の影響が大きい.

・II上品さ：玉の装飾は上品さを低める.ループ数はあま り影響しないが， 5 本の水引のみ例外で， 2 ループより ループなしが上品さを高める。 また, 水引の本数が少な い右上配置の梅結び（梅帯3）の場合, 上品さを高める.

・III好ましさ：水引の本数はあまり影響しないが，帯を持 たない抱き淡路結び (抱淡(2)）のみ例外で, 水引の本数 を増やすと，好ましさを高める．また，ループなしに比

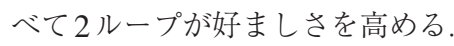


・IV目新しさ:玉の装飾および, 1ループが目新しさを高める.

・V愛らしさ : ループ数の増加により愛らしさを高め, 玉の装 飾はさらに愛らしさを高める.

\section{因子分析の結果 (二因子間)}

・MCDによるロバスト相関分析より,「II - I , III, IV」因子 間に負の相関，それ以外の因子間で正の相関が認められた。

- 水引の本数の増減が「 I - II, III, IV」因子間に, 玉や梅の 装飾の有無が「 $\mathrm{I}-\mathrm{V}\rfloor, 「 \mathrm{II}-\mathrm{IV}, \mathrm{V}\rfloor$ 因子間に, 淡路結び の特性が「II - III, IV，V」因子間に影響する.

\section{可視化ツールの詳細}

・ SUS スコアが70 以上であり, 許容可能なインターフェース であることが認められた。

・従来手法である静止画像による可視化提示に比べて, 見や すく満足度の高いツールであることが実証された。

・淡路結びは, 伝統的結びでありながら, 現代的にアレンジ した印象も兼ね備えた結びであることが確かめられた。

\section{全体の考察}

水引特有の傾向として, 上品さ因子と他の因子間に負の相関 がみられたことが挙げられる。リボン装飾の調査結果 [14]で は, 上品さの高い装飾は, 絢爛さ, 好ましさ, 愛らしさも高い 傾向にあった。これは, 上品さの演出に必要な要素が, 水引 とリボンで異なることを示す。 高階 [21] は, 日本人の美意識に 「切り捨ての美学」が根付いており, 工芸品といった生活用具 においても同様の美意識があると述べている. 水引の調査結 果では, 簡素な見た目の伝統的な結び (例:結び切り)において, 上品さのみ高く他の印象が低い傾向がみられた．伝統的な 結びは,「切り捨ての美学」によりシンプルな装飾として制作さ れていると考えられ，余分なものが削がれ洗練された様子が 上品さを演出している，一方，筒井ら [22]の報告によると， リボンは「多量の装飾により, 高貴な身分や権力, または威厳 などを示す標として使用されていた.」とあり，見た目の華やか な様子が上品さを演出している. すなわち, リボンの装飾は 動的, 水引の装飾は静的な様子が, それぞれ上品さを演出し た結果, 印象構造の違いをもたらしたものと考えられる.

絢爛さ，好ましさ，愛らしさの因子間は，それぞれ正の 相関がみられ, 文献 [14] と同じ傾向であることから, 結び の装飾が持つ共通の印象構造だといえる。 そのため, 若年層 向けに水引をアレンジする場合, 絢爛で愛らしい印象を演出 することで, より好まれる装飾となる。しかしながら, 前述 のとおり水引装飾が本来持っている上品さを損なう可能性も ある。

図4は, 「淡(3)5, 松結 5, 結切 5」を可視化ツール（5因子 表示）にて比較した結果である。ここでは，全体，絢爛さ， 上品さの印象が高い結びとしてそれぞれ選定した，図4 「淡(3) 5, 松結 5」の結果 (黄色と緑色) でも, 絢闌さが高い と上品さ以外の印象も高いことが確かめられるが, 「淡(3)5」 の結果 (黄色)のみ, 上品さの項目も「結切 $5 」$ の結果 (赤色) に近い数值を示している。 この理由として, 淡路結びが伝統 的な印象と現代的な印象を兼ね備えた結びである点が挙げら れる。「淡(3)5」は, 淡路結びを右位置に置くアレンジにより,

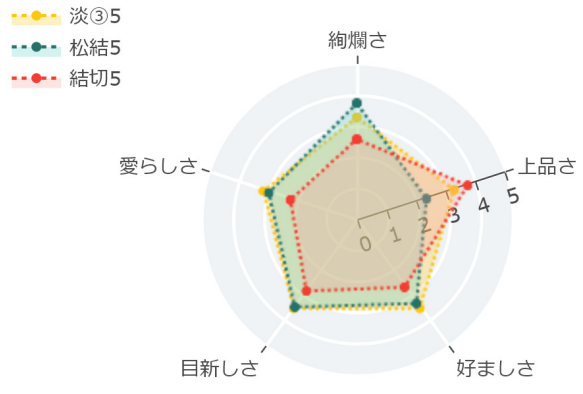

図4 比較結果 (5因子表示)

両印象を上手く両立させた良いアレンジ例である，アレンジ を考案するにあたり，単に絢爛さを高めて好ましさや愛らし さを演出するだけでなく, 水引が本来持つ上品さを考慮し て，不易流行により新たなアレンジを考えることも重要だと いえる。

\section{将来の展望}

今後は，他の結びや用途を想定した調査を進めるとともに， 異なる世代や外国人が抱く印象の違いについてもそれぞれ 明らかにしていく必要がある。加えて, 可視化ッールについ ては, 分かりやすさを向上させるために, スマートフォン 対応のインターフェースを追加実装することが改善策として 挙げられる。本改善策は, ユーザビリティの向上も期待でき, より幅広いユーザに有用なツールとなることが見込める。

\section{参 考 文 献}

［1］古川貴士, 高井由佳, 後藤彰彦, 桑原教彰, 来田宣幸 : 異なる糊を使用した京友禅染に扔ける感性評価と価格設定と の関係, 日本感性工学会論文誌, 13(1), pp.299-305, 2014.

[2] 上原義子：伝統的工芸品の現状とマーケティング課題につ いて：伝統的陶磁器の流通問題と付加価值の視点から, 嘉悦大学研究論集, 58(1), pp.85-105, 2015.

[3］宮田一乘, 梶井紀孝, 餘久保優子, 加藤直孝：工芸素材の 質感表現手法を活用したデザイン支援システムの開発（シス テム開発論文特集), 電子情報通信学会論文誌. D, 情報 · システム, 96(10), pp.2351-2358, 2013.

[4] 内野敏子：水引基本の結びと暮らしの雑貨, 文化出版局, 2017.

[5] 長浦ちえ：はじめての水引アレンジ, 世界文化社, 2018 .

[6] 横溝賢, 村井麻里子: 伊予水引のリデザイン, デザイン学 研究作品集, 15(1), pp.24-27, 2010.

[7] 横溝賢, 佐々牧雄, 村井麻里子：日本の伝統工芸品の輸出に おけるコンテキスト情報の影響, デザイン学研究，59(5)， pp.33-40, 2013.

[8］領家美奈, 長瀬可奈, 中森義輝 : 伝統工芸素材の感性評価と デー夕解析, 感性工学研究論文集, 7(4), pp.633-640, 2008.

[9］山下幸裕, 領家美奈, 中森義輝 : 九谷焼図柄と九谷焼洗面 ボールの感性評価デー夕の比較分析, 日本感性工学会論文 誌, 12(1), pp.145-155, 2013. 
[10］池坊由紀, 高井由佳, 後藤彰彦, 桑原教彰：いけばな作品 評価アンケートによる未経験者と熟練者の見極めの比較, 日本感性工学会論文誌, 13(1), pp.307-314, 2014.

[11] 村山研一：飯田地域水引製造業の産地構造（調査報告）, 人文科学論集, 29, pp. 11-27, 1995.

[12]細井浩一：クリエイテイブ産業としての伝統工芸を「みせる」, 産業学会研究年報, 2017(32), pp.37-49, 2017.

[13］橋田規子, 小暮真弥子, 青山英樹 : 洗面ボール形状と人の 感性の関倸分析によるデザイン支援方法の構築, デザイン 学研究, 57(6), pp.1-8, 2010.

[14]石橋賢, 韓宇, 宮田一乘：ラッピングにおけるリボンの 装飾に関する印象調查とその可視化, 芸術科学会論文誌, 17(1), pp.41-51, 2018.

[15] 植松公威, 佐藤真衣：大学生における慰斗と水引の使い方 の理解に及ぼす「由来・歴史」教授の効果（論文編）, 東北生活文化大学東北生活文化大学短期大学部紀要, 37 , pp.17-24, 2006.

[16] 片平建史, 河崎圭吾, 荷方邦夫, 浅野隆, 武藤和仁, 李奈栄, 飛谷謙介, 白岩史, 中島加惠, 長田典子, 岸野文郎, 山本倫也: 3 次元造形物体の感性評価における主要因子, 日本感性工 学会論文誌, 15(4), pp.563-570, 2016.

[17］佐藤弘喜：自動車のフロントグリルデザインに対する感性 評価, 日本感性工学会論文誌, 16(1), pp. 51-60, 2017.

[18] McInnes, L., Healy, J., Saul, N., and Grossberger, L.: UMAP: Uniform Manifold Approximation and Projection, The Journal of Open Source Software, 3(29), 861, 2018.

[19] McInnes, L., Healy, J., and Astels, S.: hsbscan: Hierarchical density based clustering, The Journal of Open Source Software, 2(11), 205, 2017.
[20] Brooke, J.: SUS : A retrospective, Journal of Usability Studies, 8(2), pp.29-40, 2013.

[21］高階秀爾：日本美術を見る眼一東と西の出会い, 岩波書店, pp.114-126, 2009.

[22］筒井京子, 島貫真寿美, 守屋史佳 : リボンの起源とその 装飾性について, 北海道女子短期大学研究紀要, 22 , pp.17-34, 1987.

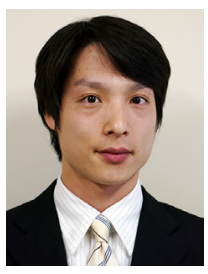

石橋 賢 (正会員)

2014 年 北陸先端科学技術大学院大学知識科 学研究科博士後期課程修了. 博士 (知識科 学). 同年, 日本学術振興会特別研究員 PD. 2015 年より熊本県立大学総合管理学部総合 管理学科講師, 2018 年 准教授, 現在に至る. 感性情報メディアの創出およびグラフィックデザインの支援に 関する研究に従事，電子情報通信学会，ACM，芸術科学会なと 各会員.

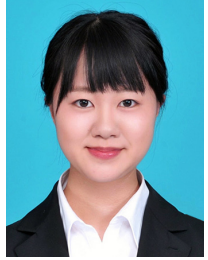

\section{上野 千尋 (非会員)}

2019 年 熊本県立大学総合管理学部総合管理 学科卒業。在籍時は, 水引装飾や写真などの 印象評価研究に従事. 